\title{
Analysis of floating house platform stability using polyvinyl chloride (PVC) pipe material
}

\author{
Aswad Asrasal ${ }^{1}$, Slamet Imam Wahyudi ${ }^{2}$, Henny Pratiwi Adi ${ }^{2, *}$, and Rick Heikoop ${ }^{3}$ \\ ${ }^{1}$ Thesis student of Civil Engineering, Sultan Agung Islamic University, Jl. Raya Kaligawe Km. 4 \\ Semarang, Indonesia \\ ${ }^{2}$ Lecturer of Civil Engineering, Sultan Agung Islamic University, Jl. Raya Kaligawe Km. 4 \\ Semarang, Indonesia \\ ${ }^{3}$ Rotterdam University of Applied Sciences, G.J. de Jonghweg 4-6, Rotterdam, The Netherlands
}

\begin{abstract}
The high demand for land to be built on, makes the price of land more expensive. Various efforts were made to get land to build houses on, one of them was by way of coastal reclamation. The pond area initially functioned as a water catchment area, but later became new land through the reclamation process. This will have adverse impacts on the environment such as flooding due to lack of water storage. To overcome the problem of building in the coastal area without reclaiming, is using floating house. A floating house is a building structure that floats on the water surface by leaning to drowned area weight as the weight parameter which the structure could handle. This research is done to analyze the material platform. PVC pipe is used with floating force $(\mathrm{Fa})$ parameter and cost plan analysis. The structure weight analysis total result is $555,887.5$ Newton. The floating force of structure platform is 648.792 Newton. The connection system is a bolt connection system that us $3 \mathrm{~cm}$ in diameter with an anchor of length $22 \mathrm{~cm}$, and a total of 4 bolts on each connection. Cost plan analysis using PVC pipe costs IDR 379.500.000,00.
\end{abstract}

\section{Introduction}

Indonesia is a country that has a water area of $70 \%$ of the total area of Indonesia. The high demand for strategic land-to-build, makes the price of land more expensive. Various efforts were made to obtain land to build houses for shelter, one of them by way of beach reclamation or pond hoarding. The area of the pond that originally functioned as a water catchment area, then became new land, which is bad for the environment due to the occurrence of floods due to lack of recharge area [1]. Based on the description of the background, this study offers the concept of a house by building without reclamation or changing the physical form of the environment, this is done with Floating house concept. The platform material from the floating house to be discussed in this study is to use PVC Pipe (polyvinyl chloride).

\footnotetext{
*Corresponding author: henni@unissula.ac.id
} 


\subsection{Problem formulation}

There are three research questions. First, how to calculate the floating house platform foundation structure's stability by using PVC pipe material toward the structural weight laying above. Second, why is the connection system among PVC pipe materials established as a floating platform structure component. And third, how is the floating house cost plan analysis using PVC pipe material as a floating platform.

\subsection{Research objectives}

The research is conducted for specific purposes as follows. First, to find out the balance of the floating house structure using PVC pipe as floating material. Second, to find out the connection system to establish PVC pipe material as floating platform. And third, to find out the floating house cost plan analysis using PVC pipe material as floating platform.

\section{Literature review}

\subsection{Floating house utilizing PVC pipe as foundation}

Floating house PVC pipe foundation is a floating house that is designed by using PVC pipe as the foundation of its structure by connecting using anchorage and bolts to the wooden blocks (sloof), so it becomes a whole structure (platform) [2]. PVC pipe is a plastic material that has an air cavity in it so it can float on the water as in Figure 1 below.

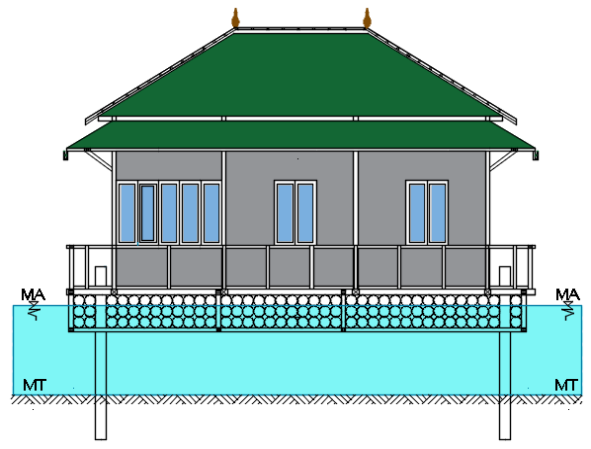

Fig. 1. Floating house with PVC pipe as floating platform foundation.

\subsection{Buoyancy force with completely submerged (Fa)}

All calculation of buoyant forces on the platform assume that the entire platform is submerged in water as follows (that is with Floating House concept). [4]

$$
\mathrm{Fa}=\left(\pi \cdot \mathrm{d}^{2} / 4\right) \cdot \rho \cdot g .1
$$

Where,

$\begin{array}{cl}\text { Fa } & \text { : Buoyancy Force with Completely Submerged }(\mathrm{N}) \\ \rho & : \text { Fluid specific mass }\left(\mathrm{kg} / \mathrm{m}^{3}\right) \\ \mathrm{d} & : \text { platform diameter } \\ \pi & : 3,14 \\ \mathrm{~g} & : \text { Specific gravity }\left(\mathrm{m} / \mathrm{s}^{2}\right) \\ 1 & : \text { platform length }(\mathrm{m})\end{array}$




\subsection{Structural stability control}

Building stability calculations can be calculated using the following formula:

$$
\mathrm{Fa}-(\mathrm{SF} . \mathrm{G})
$$

Where,

$$
\begin{array}{ll}
\mathrm{Fa} & : \text { platform } \text { floating force }(\mathrm{N}) \\
\mathrm{SF} & : \text { Safety factor }=1,2 \\
\mathrm{G} & : \text { Structure total weight }(\mathrm{kg} / \mathrm{ton} / \mathrm{N})
\end{array}
$$

\section{Research method}

\subsection{General data}

General data is information that explains the structure properties, such as type, function, and drawings. The structure data is planned (determined) by the researcher as follows: Building data is fully planned and assumed by the researcher. The Building area is $8 \mathrm{~m} \mathrm{x} 10$ $\mathrm{m}(80 \mathrm{~m} 2)$, with $3.5 \mathrm{~m}$ high building (Sloof Structure - Ringblock) and $2.5 \mathrm{~m}$ (Structure of the horses). Types of Platform Foundation with PVC Pipe are with floating system. The floating house plan can be seen in Figure 2 below.

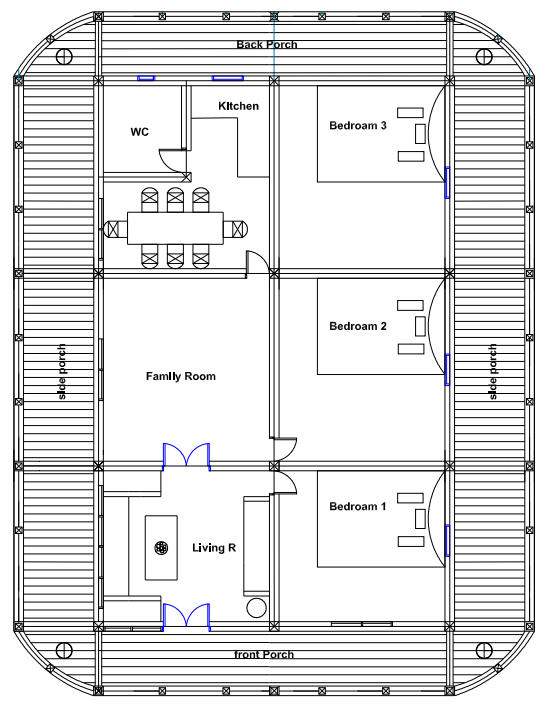

Fig.2. Floating house plan

\subsection{Upper structure}

The upper structure data is derived from structure components consisting of a few kinds of materials, detailed as follows:

\subsubsection{Sloof structure}

Dimension

Wood specimen

$: 15 \mathrm{~cm} \mathrm{x} 15 \mathrm{~cm}$

: ironwood 
Power classification

Specific weight

Pulling strength parallel to fiber

Flexural compressive strength
$: 1^{\text {st }}$ class

: $900 \mathrm{~kg} / \mathrm{m} 3$

$:<650 \mathrm{~kg} / \mathrm{cm} 2$ (absolute), $130 \mathrm{~kg} / \mathrm{cm} 2$ (permit) [5]

$:<1100 \mathrm{~kg} / \mathrm{cm} 2$ (absolute), $150 \mathrm{~kg} / \mathrm{cm} 2$ (permit) [5]

\subsubsection{Column structure}

Profile

Steel specimen

Specific weight

Pulling strength

Elasticity modulus

Shear modulus
: I. $150 \mathrm{~mm} \times 150 \mathrm{~mm} \times 50 \mathrm{~mm}$

: galvalume

: $7850 \mathrm{~kg} / \mathrm{m} 3$

: $550 \mathrm{MPa}$

$: 2,1 \times 105 \mathrm{MPa}$

: $8 \times 104 \mathrm{MPa}$

\subsubsection{Ring block structure}

Profile

Steel specimen

Specific weight

Pulling strength

Elasticity modulus

Shear modulus
: I. $150 \mathrm{~mm} \times 150 \mathrm{~mm} \times 50 \mathrm{~mm}$

: galvalume

: $7400 \mathrm{~kg} / \mathrm{m} 3$

: $550 \mathrm{MPa}$

$: 200.000 \mathrm{MPa}$

: $80.000 \mathrm{MPa}$

\subsubsection{Wall}

$\begin{array}{ll}\text { Type } & : \text { Clash Board } \\ \text { Thickness } & : 10 \mathrm{~cm} \\ \text { Weight } & : 40 \mathrm{~kg} / \mathrm{m} 2\end{array}$

\subsection{Bottom Structure (sub structure)}

Bottom structure data is the data of the platform component that consists of several types of materials that have considerable buoyancy as follows:

\subsubsection{PVC pipe}

The PVC pipe used had a length of $6 \mathrm{~m}$, diameter of 12 inch $(30 \mathrm{~cm})$, weight of $1.42 \mathrm{~kg} /$ $\mathrm{m} 2$ and thickness of $1.1 \mathrm{~cm}$.

\subsubsection{Connector}

The connector used was bolts with a diameter of $3 \mathrm{~cm}$, anchors with a diameter of $2.8 \mathrm{~cm}$ and length of $22 \mathrm{~cm}$.

\subsection{Upper structure loading}

The dead load on the floor plate was estimated to be $125 \mathrm{~kg} / \mathrm{m} 2$, wall load of $140 \mathrm{~kg} / \mathrm{m} 2$ and roof skeleton of $5.39 \mathrm{~kg} / \mathrm{m} 2$. While the planned live load includes live load on the floor plate of $100 \mathrm{~kg} / \mathrm{m} 2$ and live load on the beam of $80 \mathrm{kgf}$ (worker + tooling). The wind load was $40 \mathrm{~kg} / \mathrm{m} 2$. 


\subsection{Upper structure weight analysis}

Furthermore, the load was simulated in a structural model using SAP2000 V.16 software to calculate the total weight of the structure. The total reaction forces from the weight analysis can be used as parameters to calculate the buoyant force $(\mathrm{Fa})$ and the strength of the connection on the floating house platform structure. [3]

Based on the results of SAP2000 software analysis, the total weight of the upper structure was obtained as follows.

Table 1. Base Reaction Structure.

\begin{tabular}{|c|c|c|c|c|c|c|}
\hline $\begin{array}{c}\text { Output } \\
\text { CaseText }\end{array}$ & $\begin{array}{c}\text { Global } \\
\text { FX } \\
\text { Kgf }\end{array}$ & $\begin{array}{c}\text { Global } \\
\text { FY } \\
\text { Kgf }\end{array}$ & $\begin{array}{c}\text { Global } \\
\text { FZ } \\
\text { Kgf }\end{array}$ & $\begin{array}{c}\text { Global } \\
\text { MX } \\
\text { Kgf-m }\end{array}$ & $\begin{array}{c}\text { Global } \\
\text { MY } \\
\text { Kgf-m }\end{array}$ & $\begin{array}{c}\text { Global } \\
\text { MZ } \\
\text { Kgf-m }\end{array}$ \\
\hline Comb All & 0,000002 & $-0,0000003$ & 44557,8 & 289620 & 15524,59 & 0,000001 \\
\hline Comb All & -40 & $-2900,26$ & 21610,26 & 140462 & $-32102,7$ & $-2324,19$ \\
\hline
\end{tabular}

Total structure weight caused by working load $=44557,8$

$$
\begin{aligned}
& =44557,8 \times 10 \\
& =445578 \text { Newton }
\end{aligned}
$$

\section{Results and discussion}

\subsection{Platform floating force analysis}

Floating force analysis $(\mathrm{Fa})$ is an analysis of the magnitude of the buoyant force of a platform material which will be compared with the downward force due to the weight of the floating house structure. The platform is said to be strong if the upward force $(\mathrm{Fa})$ is bigger than the total weight of the structure $(\mathrm{G})$.

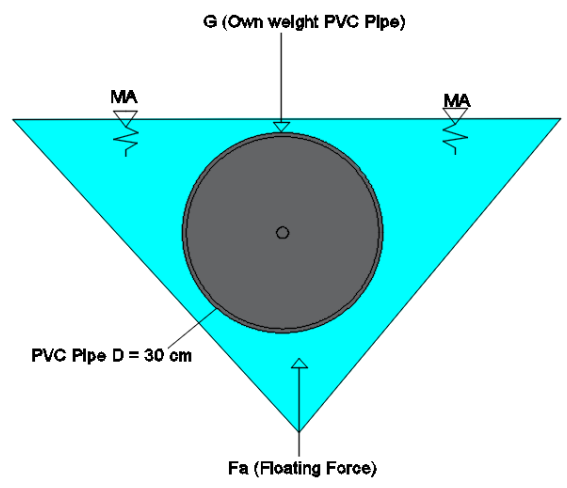

Fig. 3. PVC pipe buoyant force with completely submerged.

PVC pipe empty weight (G)

$=15,9 \mathrm{~kg} \mathrm{x} \mathrm{g}$

$=15,9 \times 10=159$ Newton

Buoyant force with completely submerged $(\mathrm{L}=6$ meter $)$

$$
\begin{aligned}
& =\pi \cdot d^{2} / 4 . \rho \cdot g \cdot L \rightarrow(\mathrm{d}=\text { inner diameter }) \\
& =(22 / 7) \times(0,28,9)^{2} / 4 \times 1000 \times 10 \times 6 \\
& =3933,84 \mathrm{~kg} / \mathrm{pipe}
\end{aligned}
$$


Total buoyant force

buoyant force for pipe 26

Buoyant force with completely submerged $(\mathrm{L}=4$ meter)

$$
=V-G
$$

$=3933,84-159$

$=3774,84$ Newton/ pipe (upward)

$=26 \times 3774,84$

$=98145,82$ Newton/layer

$=\pi \cdot d^{2} / 4$. $. g . L \rightarrow(\mathrm{d}=$ inner diameter $)$

$=(22 / 7) \times(0,28,9)^{2} / 4 \times 1000 \times 10 \times 4$

Total buoyant force

$=2622,56 \mathrm{~kg} / \mathrm{pipe}$

$=V-G$

$=2622,56-159$

$=2453,56 \mathrm{Newton} /$ pipe (upward)

Buoyant force Pipe 26

Subtotal: 98145,82+60452,54

4-layer platform PVC pipe
$=26 \times 2453,56$

$=64052,54$ Newton/layer

$=162198,4$ Newton/layer

$$
=162198,4 \times 4
$$$$
=648793
$$

\subsection{Structure balance analysis}

The structure is said to be balanced if the buoyant force $(\mathrm{Fa})$ is equal to the total weight of the structure of the house $(\mathrm{G})$ and is said to be efficient if the weight of the structure is greater than the total weight of the structure of the house $(\mathrm{G})$. [5]

Floating house Structure total weight $(\mathrm{G})=463.239,6$ Newton

SF (safety factor)

Buoyant force $(\mathrm{Fa})$

$\mathrm{Fa}-(\mathrm{G} \times 1,2)$

$$
\begin{aligned}
& =1,2 \\
& =648793 \text { Newton } \\
& =648793-(463.239,6 \times 1,2) \\
& =92905,9 \text { Newton }>0 \rightarrow \text { Ok }
\end{aligned}
$$

\subsection{Platform connection analysis}

The platform structure is connected using a bolt connector. The specifications and number of bolts are made equal for all platform material types, the connection model of the three materials is as follows [6];

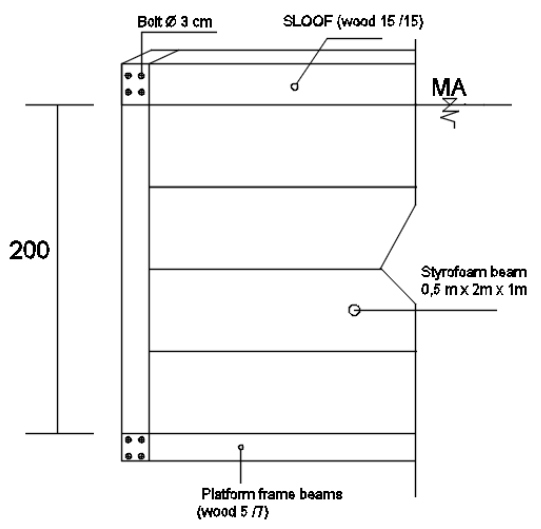

Fig. 4. Model of PVC pipe connection platform (cross-section). 


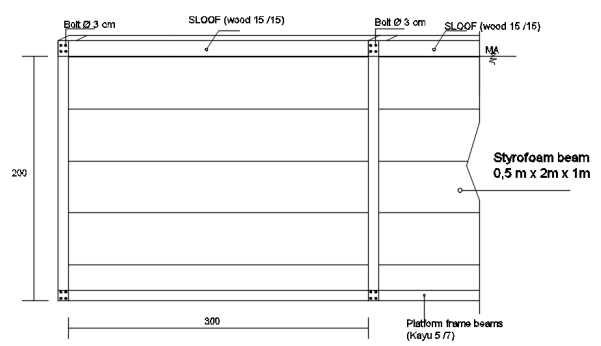

Fig. 5. Model of PVC pipe connection platform (long section).

Table 2. Recapitulation of Pipe PVC Platform Budget Plan.

\begin{tabular}{|l|l|c|}
\hline No & \multicolumn{1}{|c|}{ SPECIFIC WORK } & PRICE \\
\hline I & Preparation & 2.360 .000 \\
\hline II & Platform PVC Pipe (PVC Pipe 12 inch) & 266.840 .000 \\
\hline III & Sloof work & 6.300 .000 \\
\hline IV & Floor work & 4.975 .000 \\
\hline V & Column work & 4.830 .000 \\
\hline VI & Ring block work & 4.790 .000 \\
\hline VII & Wall work & 13.510 .000 \\
\hline VIII & Doors and Windows work & 12.970 .000 \\
\hline IX & Framework & 12.630 .000 \\
\hline X & Roof work & 7.488 .000 \\
\hline XI & Sanitation work & 5.340 .000 \\
\hline XII & Mechanical Electrical work & 2.060 .000 \\
\hline XIII & Finishing & 1.000 .000 \\
\hline Total & & IDR 345.093.000,00 \\
\hline As a whole & IDR 345.000.000,00 \\
\hline Tax 10 \% & IDR 379.500.000,00 \\
\hline Total Price & \\
\hline
\end{tabular}

\section{Conclusion and perspective}

Based on the results of the analysis, it can be concluded that the total weight of the upper structure and platform structure $(\mathrm{G})$ is equal to $555,887.5$ Newton with a safety factor of 1.2. The force of the buoyant force $(\mathrm{Fa})$ of the plate structure made of PVC Pipe material is 648,793 Newton. The connection system on the framework of the floating house platform is a bolt connection system, that is $3 \mathrm{~cm}$ in diameter with an anchor length of $22 \mathrm{~cm}$ and with a total of 4 bolts on each connection. The connection between the resin materials can use the glue to then be arranged and made one with the framework of the platform. Budget Cost Plan Analysis using PVC Pipe Materials requires a fee of IDR 379,500,000.00.

To increase the buoyancy of the platform material, the width and height of the platform can be enlarged. In order to increase the durability of the platform material PVC pipe uses 
rubber coating as a barrier between the materials so it is not easy to break from the friction of working forces. It needs a scaled prototype of material proposed by the researcher.

Thanks to the master program in Civil Engineering, Faculty of Engineering Sultan Agung Islamic University Semarang, Rotterdam University of Applied Sciences and all parties for the participation, support and good cooperation.

\section{References}

1 S.I. Wahyudi, R. Heikoop, H.P. Adi, T. Overgaauw, B. Schipper, Emergency Scenarios in the Banger polder, Semarang City (A case study to Identify Different Emergency Scenarios), Water Practice and Technology, 12, 3, pp. 637-648 (2017).

2 Ambica et al, Floating Architecture. A Design on Hidrophilic floating House for Fluctuating Water Level. Bharath University. Indian Journal of Science and Technology, 8, 32 (2015)

3 A. Wiguna, E. Walujodjati, Analisis Kekuatan Baja Canai Dingin (Cold Formed Steel) Sebagai Alternatif Untuk Elemen Struktur Balok Rumah Sederhana Yang Merespon Gempa, Jurnal Kalibrasi, 13, 1 (2015)

4 Zakki et al, 2014. Perencanaan Bangunan Apung Dan Keramba Dengan Sitem Modular Ponton Berbahan Fero semen, Jurnal Teknik Perkapalan, 4, 3 (2014)

5 S.I. Wahyudi, Perencanaan Floating Podium di Polder Stasiun Tawang, Proposed Floating House, Semarang (2016)

6 SNI Kayu, Spesifikasi Desain Untuk Struktur Kayu, Badan Standar Nasional, 3 (2013) 